\title{
ASSESSING THE FUTURE: METHODS AND CRITERIA
}

\author{
I. Gräßler, H. Thiele ${ }^{\bowtie}$ and P. Scholle \\ Paderborn University, Germany \\ $\square$ henrik.thiele@hni.upb.de
}

\begin{abstract}
As time-to-market is getting shorter, customer needs have to be identified as early as possible in product development. Correctly applied, corporate foresight can give a glimpse into the future to anticipate such needs and thus gain a competitive advantage. A support tool to choose the appropriate method of foresight is not available yet. Thus, a literature study on foresight methods in industry is performed and a novel decision support tool is proposed which avoids high entrepreneurial risks. Based on the findings, potentials for future work are identified for different types of methods.
\end{abstract}

Keywords: empirical studies, design support system, decision making, foresight, decision support tool

\section{Introduction}

As time-to-market and product life cycles are getting shorter, the need for corporate foresight increases. New customer needs as well as market trends or technological development and new emerging technologies have to be anticipated fast to take a favourable position in comparison to competitors. This anticipation is needed in order to identify potentials for a market pull and technology push. As the future is characterized by ambiguity, there is not one possible future, but multiple futures. (Reibnitz, 1992)

Methods of foresight, as scenario technique or trend extrapolation, are therefore used in the context of strategic management (Reibnitz, 1992; Götze, 1993) deriving future societal or environmental scenarios. Other application examples support product development itself in identifying emerging technologies (Randt, 2015). Large producing companies apply methods of foresight often to obtain an understanding of these futures. (EFNM, 2009) During product development, this understanding is used as decision support and to turn promising ideas into successful innovations, as in the action field of Product Creation the strategic planning combined with methods of foresight represents a first and necessary step towards successful products. (Gräßler, 2015) Within product development, methods of foresight serve different purposes. Synergies of scenario technique, as a method of corporate foresight, with Systems Engineering have been investigated and shown successful (Gräßler et al., 2016), as well as the benefit for deriving future robust modular product architectures (Greve and Krause, 2018).

As there is a variety of possible methods, a sound information basis for the selection of a method is needed, as all methods yield good results only when applied correctly. Some methods imply high application efforts. If they are applied in a wrong or ineffective manner, the financial risk for the company is high. The presented work includes a literature review of foresight methods and maps them to time and reason of application. The result is a novel decision support tool to choose the right method of foresight to avoid the mistake of applying an unsuitable method and thus risking a financial loss. The resulting table is evaluated and potentials for future research are identified. 


\section{State of the art}

In order to assess existing foresight methods, a literature study is motivated (c.f. section 2.1), performed (c.f. section 2.2 and 2.3) and the results are compiled and assessed (c.f. section 2.4).

\subsection{Terminology and need}

The need for strategic foresight was expressed by various authors in the second half of the $20^{\text {th }}$ century. Krystek and Stewens (1992) date the establishment of corporate foresight to the late 1960s and divide the following years into different generations of foresight:

- $\quad 1^{\text {st }}$ Generation (1970-1975): Early warning - key figures, determined by extrapolation

- $\quad 2^{\text {nd }}$ Generation (1975-1980): Operational early detection - indicators for opportunities and risks

- $\quad 3^{\text {rd }}$ Generation (1980-1990): Strategic early detection - Potentials and risks by weak signals

- $4^{\text {th }}$ Generation (1990 until now): Strategic foresight - integrative approaches and networked thinking to identify potential opportunities and risks and derive actions

Building on this list, Daheim and Uerz (2008) see open foresight, an analogy to open innovation, as the next generation of corporate foresight, where external partners give input to foresight projects. This argumentation fits to the first notion of scenario technique as method of corporate foresight, used by the Shell Corporation. Herman Kahn developed the methods at the RAND Corporation (Kahn and Wiener, 1967) which became known during the international oil crisis. Shell, as a company, was unable to predict the oil crisis, but saw the possibility of such an event, by performing scenario technique to derive different options for future development. (Wack, 1985) While most other oil companies pursued a linear, demand-driven strategy until the 1973 international oil crisis, Shell included in their contracts a relapse option for a decline in production and was therefore able to survive this crisis by reacting to the disruptive event with a strategy change. According to the terminology used by Fink and Schlake (2000) the study on looking to the future is therefore be divided into two series of methods:

- Foresight: Different, equally possible, feasible, desirable futures without regards to probability

- Forecast: Determination of the most exact and probable future

Various authors have developed a broad range of methods for both foresight and forecast. Pillkahn (2008) further subdivides existing methods of forecasting into different categories. While all methods are suitable for corporate foresight, only those that "look to the future" provide a picture of the future:

- Methods of looking into the future, e.g. scenario technique

○ Causal Logic, e.g.: simulations

- Time Series, e.g. trend extrapolation

- Laws and Theories, e.g. S-curve analysis

- Fantasy and Creativity, e.g. Fantasy

- Shaping, e.g. conclusions

- Methods of analysing the presence, e.g. patent analysis

- Methods of forming an opinion: e.g. expert panels

The seven identified categories are later used by the authors, where scenario technique is a mix of different methods. According to Bradfield et al. (2005), the methods for deriving scenarios usually belong to three different schools, which differ greatly in the methods used:

- Intuitive logics, using delphi-studies and other discursive methods

- Cross-Impact methods, using trend extrapolation

- Consistency based methods, using mathematical methods of enumeration

Within the presented categories, different methods were developed which are used under different conditions and environments. Especially large producing companies regularly apply methods of foresight (EFMN, 2009), but small and medium companies still hesitate to apply such methods due to the high effort (Gräßler et al., 2018, 2019). As all methods yield good results only under the right circumstances, a guide to when apply which method is needed. Therefore, all relevant methods are 
investigated, mapped to the previously given categories and subsequently evaluated and visualized. A user can use the presented Table 2 to choose the right methods, given the circumstances of application.

\subsection{Methods of foresight}

Various methods of foresight have been published, with some authors publishing a compilation of methods, each with a different focus. It is worth mentioning that Zürni publishes various methods for analysing the presence to obtain information about the future (2004) Lichtenthaler, ranking a set of methods with regards to objectivity (Lichtenthaler, 2005) or Burmeister (2002), who investigates the application in industry. Systematic research in the field of futurology has been carried out with different emphases, e.g. frequency of use (Butter and Popper, 2008; Keenan, 2007), geographical specialities (Popper and Teichler, 2011) or historical development and future hints (Iden et al., 2017).

In the present work, a meta-study was conducted to consolidate the data. In the databases of Google Scholar and Science Direct, publications with different foresight methods were collected using keywords such as "Foresight", "Forecasting", "Meta-Study" or "Literature Study". Subsequently, the methods mentioned more than once were divided into the categories defined by Pillkahn (2008). These categories represented a good balance between a diverse distribution and a manageable number of categories. The studies, examining the application, were conducted among industrial practitioners, e.g. by Popper and Teichler (2011), and estimate or state either the numbers of application or the number of companies interviewed. Therefore, the sum of all mutually exclusive cases of application considered in the results of the meta-study is estimated to be higher than 5000. The review followed the methodology by Machi and McEvoy (2012) and resulted in the Table 1. Those methods, which are most commonly used in each category as identified by Butter and Popper (2008), are printed in bold in Table 1:

Table 1. Review of methods of foresight

\begin{tabular}{|c|c|c|}
\hline \multicolumn{2}{|c|}{ Type of methods } & Method \\
\hline \multirow{5}{*}{ 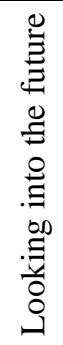 } & Causal logic & calculations, simulations \\
\hline & Time Series & indicators, scanning, trend extrapolations \\
\hline & $\begin{array}{l}\text { Laws and } \\
\text { Theories }\end{array}$ & $\begin{array}{l}\text { economic cycles, historical analogies, key-technologies, lifecycle analysis, mega trend } \\
\text { analysis, repetitions, roadmaps, S-curve analyses, theories, weak signals }\end{array}$ \\
\hline & Fantasy & $\begin{array}{l}\text { brainstorming, delphi studies, essays, fantasy, genius forecasting, intuition, role } \\
\text { play/acting, scenario writing, science fiction, survey of experts }\end{array}$ \\
\hline & Shaping & backcasting, conference/ workshop on the future, conclusions, planning cell, roadmaps, \\
\hline \multicolumn{2}{|c|}{$\begin{array}{l}\text { Methods of } \\
\text { analysing the } \\
\text { presence }\end{array}$} & $\begin{array}{l}\text { analysis of public opinion, benchmarking, cross-impact analysis, decision matrix, } \\
\text { experience curves, enterprise environment analysis, literature review, link to public, } \\
\text { lead users, mind mapping, network plan technique, number of publications, option } \\
\text { pricing, patent analysis (number of patents, patent network), portfolios, structural } \\
\text { analysis, SWOT analysis, technology-portfolio analysis, literature review }\end{array}$ \\
\hline \multicolumn{2}{|c|}{$\begin{array}{l}\text { Methods of forming } \\
\text { opinion }\end{array}$} & $\begin{array}{l}\text { citizen panels, delphi method, decision matrix, expert opinion, expert panels, flexible } \\
\text { survey of experts, game and decision theory, group opinion, interview, intuition, mind } \\
\text { mapping, multi-criteria analysis, polling/voting, questionnaire, ranking, relevance tree, } \\
\text { stakeholder mapping }\end{array}$ \\
\hline
\end{tabular}

\subsection{Criteria of foresight}

In addition to various methods of forecasting, criteria for implementation are identified. In particular, publications in the field of scenario planning provide several criteria as to when a certain method is applied (Götze, 1993; Klüfers et al., 2017; Bradfield et al., 2005; Amer et al., 2013). Different criteria were identified using the same methodology as in section 2.2. Most of the criteria were given implicitly by the evaluation of methods according to certain criteria, e.g. Lichtenthaler (2005) in Figure 1, mapping the time span against the type of method (qualitative $\rightarrow$ quantitative). In total, more than 50 criteria were identified through the literature study and subsequently divided into three categories:

- Environment of the future: description of the environment and the type of future to be assessed

- Input: Prerequisites for implementing the method and the data used

- Methodological aspects: Characteristics of the method 


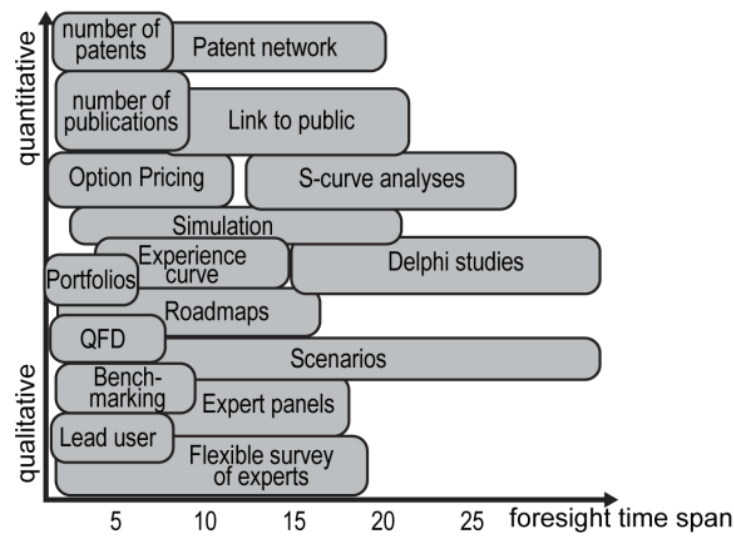

Figure 1. Methods of previewing technologies (adjusted based on (Lichtenthaler, 2005))

All identified criteria are classified into the specified categories. The look into the future can be divided into scope and time span. The scope describes whether the target image of the future is considered a broad or narrow focus and the time frame how far into the future one looks.

In comparison to the scenario cone proposed by Reibnitz (1992), the time frame describes the length of the cone and the scope represents the diameter of the cone. (Pillkahn, 2008; Lichtenthaler, 2005; Bradfield et al., 2005) Since the future under investigation is volatile, volatility is represented by the speed and nature of the change. The rate of change is evaluated from fast to slow and disruptive, and the type of change is described by the following attributes (Pillkahn, 2008):

- Constant state - the range of paradigms: Nearly stable conditions, as they are characterized by physical constants and cycles in the universe (tides, seasons)

- Focused change - the area of trends: foreseeable (cyclic, wave-shaped, evolutionary ...) changes

- Unfocused change - the area of uncertainty: Typified by economic and financial systems, or scientific discourse in the absence of clear answers.

- Wildcards - chaos: Surprises which cannot be foreseen.

With the speed and type of change to be given, the turbulence of the system hast to be studied to complete the view of volatility. In the context of foresight, turbulence occurs in the form of: recurring, expanding, changing, uncertain, surprising (Ansoff and McDonnell, 1990).

Since the future itself is uncertain, the uncertainty of the future picture can be classified. Courtney et al. (1997) defined four different types of uncertainties about the future:

- $\quad$ surprise free future: The situation is stable and no surprises are to be expected.

- alternative future: There are a number of different options and alternatives

- range of various futures: Uncertain situation with many factors and dependencies.

- Uncertainty: Highly dynamic and complex situations associated with a lack of knowledge.

The input category is divided into four criteria. First, the type of method is examined, ranging from qualitative to quantitative (Lichtenthaler, 2005). This can be applied both to the type of data required and to the amount of data needed to implement the method. The data is also evaluated toward its orientation as the starting point of the analysis. Data and knowledge is either obtained from the past, e.g. by extrapolation, generally valid, i.e. laws and theories, or future-oriented, e.g. scenarios. The input is classified according to the basis by deriving the input data (Pillkahn, 2008):

- Knowledge: corresponds to the state of the art and is verifiable by facts;

- Sound opinion: sufficient evidence available to allow a safe assumption;

- Supposition: One can come to a conclusion by compiling the evidence and assumptions;

- Speculation: This level is characterized by hopes, beliefs, wishes and fears.

Since Pillkahn also defines elements of the future as chaos/wildcards, uncertainties, contradictions, trends, constants/paradigms, the previously defined spectrum of knowledge and change is mapped against each other to visualize the spectrum of application (Figure 2): 


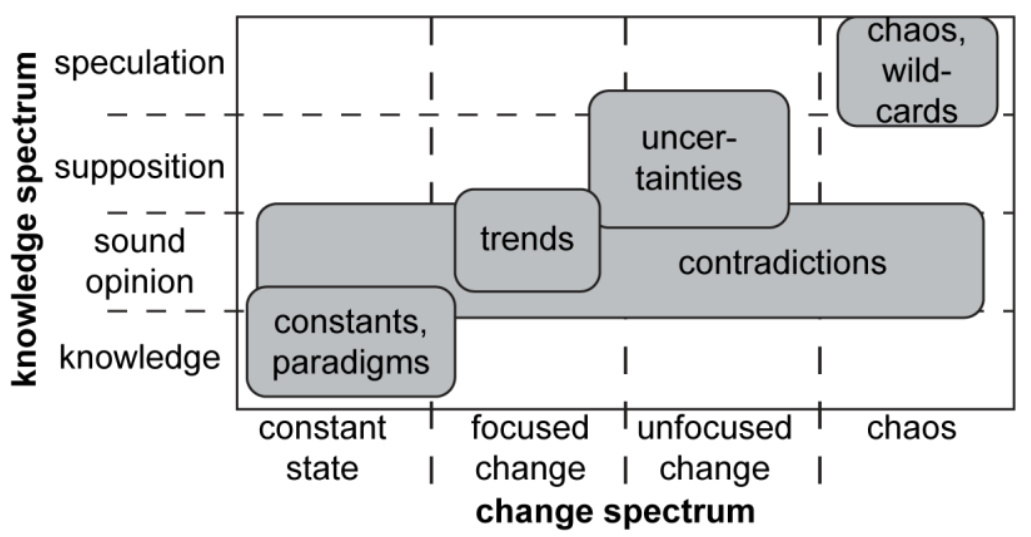

Figure 2. Elements of the future, change and knowledge (adjusted based on (Pillkahn, 2008))

While the previous criteria give an overview of the target area which the user wants to investigate, methodological aspects give an understanding of the applicability of the method for a potential user. The frequency of application can be examined, divided into case-related and regular application (Burmeister, 2002), as well as the methodology, which is either process- or result-oriented. While narrative methods, such as Delphi studies, are process-oriented, most numerical methods, such as trend extrapolation, are considered result-oriented. (Bradfield et al., 2005)

With regard to the implementation of a certain method, the user considers three different aspects: Effort, team and tools used. The effort, ranging from high to low, is considered as the sum of time, money and complication. Some methods rely on the help of experts. The foresight team can either be made up of company members (internal), external help (internal + experts) or external. The nature of the foresight team is partially reflected in the tools used. While methods that use digital tools may require external help, most workshop-based methods may require an external or internal facilitator. (Amer et al., 2013)

The evaluation criteria and the results are closely linked to the tools used. These are method-specific, but can be generalized according to the categories, since, for example, time series methods usually use statistics and shaping methods provide a strategy on how to achieve the desired future (Pillkahn, 2008).

\subsection{Decision support tool for foresight methods}

The results of the literature study in sections 2.2 and 2.3, are visualized by identifying characteristics of the methods in the categories for the selected criteria. For each category, an exemplary method is selected from Table 1 with regard to representability of the category and the number of applications (Butter and Popper, 2008). As scenario technique is often used but cannot be sorted into an explicit category, it is represented as a method mix, but an overall result of methods in this category cannot be assumed.

To choose a method of foresight, the user must know the company's current situation. If there is no such data available, methods of analysing the presence with low resource needs, e.g. SWOT analysis, have to be applied. This data, together with the resources available build the first step in choosing a method. Financial and staff resources need to be checked to evaluate whether external help is needed and can be afforded. With limited resources, many methods, especially Time Series methods, are unsuitable. Second, the involvement of the client, e.g. upper management of one's own company, and the purpose need to be cleared. Third, the environment of the future needs are to be defined and verified with the client. There must be agreement especially about the scope to avoid unnecessary iterations. Forth, the information which can be made available to the foresight team need to be researched. By exclusion, a clear image on which method to choose is available. The remaining criteria have to be considered as free variables and help the user to decide between the remaining methods.

The novel decision tool comprises the thorough method collection (Table 2) and the above described application steps, thus aiding the user in choosing the appropriate method. As such a decision support tool does not yet exist and available literature reviews rely on less criteria and fewer methods, the risk of choosing an inappropriate method is reduced significantly. 
Table 2. Evaluation of representative methods

\begin{tabular}{|c|c|c|c|c|c|c|c|c|c|}
\hline & $\begin{array}{l}\text { Causal } \\
\text { Logic }\end{array}$ & Time Series & $\begin{array}{l}\text { Laws and } \\
\text { theories }\end{array}$ & Fantasy & Shaping & Mixture & Presence & $\begin{array}{l}\text { Finding } \\
\text { opinion }\end{array}$ & \\
\hline $\begin{array}{l}\text { Exam- } \\
\text { ples }\end{array}$ & $\begin{array}{l}\text { Calculations, } \\
\text { simulations }\end{array}$ & $\begin{array}{l}\text { Trend } \\
\text { extrapolation }\end{array}$ & $\begin{array}{l}\text { theories/ } \\
\text { analogies }\end{array}$ & \begin{tabular}{|l|} 
Delphi \\
studies, \\
Brainstorming
\end{tabular} & Roadmap & Scenarios & $\begin{array}{l}\text { Patent } \\
\text { Analysis }\end{array}$ & $\begin{array}{l}\text { expert } \\
\text { opinion }\end{array}$ & \\
\hline Scope & narrow & narrow & $\begin{array}{l}\text { narrow to } \\
\text { broad }\end{array}$ & broad & narrow & $\begin{array}{l}\text { broad to } \\
\text { narrow }\end{array}$ & narrow & broad & \\
\hline $\begin{array}{l}\text { Time } \\
\text { frame }\end{array}$ & $\begin{array}{l}\text { short to } \\
\text { medium }\end{array}$ & $\begin{array}{l}\text { short to } \\
\text { medium }\end{array}$ & $\begin{array}{l}\text { short, } \\
\text { medium }\end{array}$ & \begin{tabular}{|l} 
medium to \\
long
\end{tabular} & $\begin{array}{l}\text { short to } \\
\text { medium }\end{array}$ & $\begin{array}{l}\text { medium to } \\
\text { long }\end{array}$ & $\begin{array}{l}\text { short, } \\
\text { medium }\end{array}$ & all & \\
\hline Speed & fast and slow & medium & all & $\begin{array}{l}\text { slow, } \\
\text { disruptive }\end{array}$ & slow & $\begin{array}{l}\text { slow, } \\
\text { disruptive }\end{array}$ & slow & slow & \\
\hline Change f & focused & focused & $\begin{array}{l}\text { constant, } \\
\text { focused, } \\
\text { (unfocused) }\end{array}$ & $\begin{array}{l}\text { unfocused, } \\
\text { chaos }\end{array}$ & $\begin{array}{l}\text { un/- } \\
\text { focused }\end{array}$ & $\begin{array}{l}\text { un- } \\
\text { /focused, } \\
\text { chaos }\end{array}$ & $\begin{array}{l}\text { constant, } \\
\text { focused } \\
\text { change }\end{array}$ & $\begin{array}{l}\text { unfocused } \\
\text { change, } \\
\text { chaos }\end{array}$ & \\
\hline $\begin{array}{l}\text { Turbu- } \\
\text { lence }\end{array}$ & $\begin{array}{l}\text { recurring, } \\
\text { expanding }\end{array}$ & $\begin{array}{l}\text { recurring, } \\
\text { expanding, } \\
\text { changing }\end{array}$ & $\begin{array}{l}\text { recurring, } \\
\text { expanding, } \\
\text { changing }\end{array}$ & $\begin{array}{l}\text { recurring, } \\
\text { expanding, } \\
\text { changing, } \\
\text { surprising }\end{array}$ & $\begin{array}{l}\text { recurring, } \\
\text { expanding }\end{array}$ & $\begin{array}{l}\text { recurring, } \\
\text { expanding, } \\
\text { changing }\end{array}$ & & $\begin{array}{l}\text { recurring, } \\
\text { expanding, } \\
\text { changing }\end{array}$ & 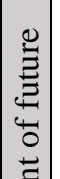 \\
\hline $\begin{array}{l}\text { Uncer- } \\
\text { tainty }\end{array}$ & $\begin{array}{l}\text { surprise } \\
\text { free }\end{array}$ & $\begin{array}{l}\text { surprise } \\
\text { free }\end{array}$ & \begin{tabular}{|l} 
alternative, \\
range of \\
various
\end{tabular} & $\begin{array}{l}\text { range of } \\
\text { various, } \\
\text { uncertainty }\end{array}$ & uncertainty & $\begin{array}{l}\text { alternative, } \\
\text { range of } \\
\text { various, } \\
\text { uncertainty }\end{array}$ & uncertainty & $\begin{array}{l}\text { range of } \\
\text { various, } \\
\text { uncertainty }\end{array}$ & 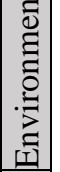 \\
\hline Nature & quantitative & $\begin{array}{l}\text { mostly } \\
\text { quantitative }\end{array}$ & \begin{tabular}{|l} 
mostly to \\
fairly \\
qualitative
\end{tabular} & qualitative & $\begin{array}{l}\text { fairly } \\
\text { qualitative }\end{array}$ & $\begin{array}{l}\text { fairly } \\
\text { qualitative }\end{array}$ & quantitative & qualitative & \\
\hline Amount & very high & high & medium & $\begin{array}{l}\text { medium to } \\
\text { low }\end{array}$ & $\begin{array}{l}\text { medium, } \\
\text { low }\end{array}$ & medium & high & $\begin{array}{l}\text { medium } \\
\text { to low }\end{array}$ & \\
\hline \begin{tabular}{l|} 
Know- \\
ledge
\end{tabular} & $\begin{array}{l}\text { knowledge, } \\
\text { sound } \\
\text { opinion }\end{array}$ & $\begin{array}{l}\text { sound } \\
\text { opinion, } \\
\text { supposition }\end{array}$ & $\begin{array}{l}\text { knowledge, } \\
\text { supposition }\end{array}$ & speculation & supposition & supposition & knowledge & supposition & \\
\hline $\begin{array}{l}\text { Orien- } \\
\text { tation }\end{array}$ & $\begin{array}{l}\text { centered on } \\
\text { past }\end{array}$ & $\begin{array}{l}\text { centered on } \\
\text { past }\end{array}$ & $\begin{array}{l}\text { generally } \\
\text { valid }\end{array}$ & $\begin{array}{l}\text { centered on } \\
\text { future }\end{array}$ & $\begin{array}{l}\text { centered } \\
\text { on future }\end{array}$ & $\begin{array}{l}\text { centered on } \\
\text { future }\end{array}$ & $\begin{array}{l}\text { centered on } \\
\text { the present }\end{array}$ & all & 三 \\
\hline Purpose & $\begin{array}{l}\text { mostly case- } \\
\text { specific }\end{array}$ & $\begin{array}{l}\text { mostly case- } \\
\text { specific }\end{array}$ & $\begin{array}{l}\text { case- } \\
\text { specific }\end{array}$ & $\begin{array}{l}\text { case-specific } \\
\text { to regular }\end{array}$ & $\begin{array}{l}\text { case- } \\
\text { specific }\end{array}$ & $\begin{array}{l}\text { regular to } \\
\text { case- } \\
\text { specific }\end{array}$ & regular & equal & \\
\hline $\begin{array}{l}\text { Metho- } \\
\text { dology }\end{array}$ & $\begin{array}{l}\text { outcome- } \\
\text { oriented }\end{array}$ & $\begin{array}{l}\text { outcome- } \\
\text { oriented }\end{array}$ & $\begin{array}{l}\text { Process- } \\
\text { oriented }\end{array}$ & $\begin{array}{l}\text { process- } \\
\text { oriented }\end{array}$ & $\begin{array}{l}\text { outcome } \\
\text { oriented }\end{array}$ & $\begin{array}{l}\text { outcome/ } \\
\text { process- } \\
\text { oriented }\end{array}$ & $\begin{array}{l}\text { outcome } \\
\text { oriented }\end{array}$ & $\begin{array}{l}\text { process- } \\
\text { oriented }\end{array}$ & \\
\hline Effort & high & $\begin{array}{l}\text { medium to } \\
\text { high }\end{array}$ & $\begin{array}{l}\text { (medium } \\
\text { to) low }\end{array}$ & $\begin{array}{l}\text { medium to } \\
\text { low }\end{array}$ & high & $\begin{array}{l}\text { medium to } \\
\text { high }\end{array}$ & medium & medium & \\
\hline Team & external & external & $\begin{array}{l}\text { external } \\
\text { and internal }\end{array}$ & $\mid \begin{array}{l}\text { internal } \\
(+ \text { external })\end{array}$ & internal & $\begin{array}{l}\text { internal } \\
\text { and } \\
\text { external }\end{array}$ & internal & experts & \\
\hline $\begin{array}{l}\text { Tools } \\
\text { used }\end{array}$ & computer & $\begin{array}{l}\text { computer } \\
\text { tools }\end{array}$ & $\begin{array}{l}\text { workshop } \\
\text { (literature } \\
\text { study) } \\
\end{array}$ & workshop & workshop & \begin{tabular}{|l} 
computer \\
based, \\
workshop \\
\end{tabular} & research & workshop & $\begin{array}{l}\mathscr{0} \\
\ddot{\mathscr{U}} \\
\end{array}$ \\
\hline Criteria & models & statistics & $\begin{array}{l}\text { analogies, } \\
\text { current } \\
\text { trends }\end{array}$ & internal logic & feasibility & $\begin{array}{l}\text { internal } \\
\text { coherence, } \\
\text { relevance, } \\
\text { probability }\end{array}$ & diverse & $\begin{array}{l}\text { internal } \\
\text { logic }\end{array}$ & $\begin{array}{l}\frac{\pi}{7} \\
\frac{0}{0} \\
0 \\
0 \\
0 \\
0 \\
0\end{array}$ \\
\hline \begin{tabular}{|l|l} 
Output \\
\end{tabular} & $\begin{array}{l}\text { numerical } \\
\text { values }\end{array}$ & \begin{tabular}{|l} 
numerical \\
values
\end{tabular} & narrative & narrative & strategy & scenarios & $\begin{array}{l}\text { technologic } \\
\text { future }\end{array}$ & assessment & $\stackrel{8}{\frac{\pi}{0}}$ \\
\hline
\end{tabular}




\section{Evaluation}

In the action field of Product Creation, corporate foresight and strategic planning proceeds product development (Gräßler, 2015). Therefore, methods of corporate foresight are an integral prerequisite of identifying promising new products and thus ensure successful market launch. In section 3.1., a formal evaluation is carried out and in section 3.2 potentials for each set of methods are identified.

\subsection{Formal evaluation}

To evaluate the presented result, a support evaluation and an application evaluation for decision support tools in design research, following the methodology by Blessing and Chakrabati (2009), is performed. First, the support evaluation evaluates the definition of the support problem. The researched methods of foresight and application criteria were developed based on a literature review and thus implicitly review more than 5000 different cases in the industry (c.f. section 2.2). Most of the cases came from producing companies. As only support tools with less methods or criteria exist, a significant gain is recorded.

The two criteria to be evaluated in the application evaluation are applicability and usability. The question to be answered is: Can the support be used? (Blessing and Chakrabarti, 2009)

Since the results come from a broad variety of already used methods, the applicability of the methods already is proven. The compiled results in Table 2 contain up to 17 criteria, with mainly two to four attributes, for 8 different categories of methods. The compact representation of the results facilitates the use of the results for the user and due to the limited possibilities usability is assumed.

\subsection{Identified potentials}

Reviewing the results displayed in Table 2 critically, the following potentials for future work on the different sets of methods is identified:

Causal Logic and Time Series: The given methods deliver good results on the basis of quantitative results, but are heavily dependent on external help from specialists and experts. Potentials for future work are identified by creating a platform for a broader range of foresight and a lower entry barrier for the implementation of the methods and thus less effort.

Laws and theory: Methods in this area use the knowledge of past events to formulate generally valid assumptions. For example, as time-to-market and product lifecycles for new products are decreasing, existing methods need to be constantly reviewed to guarantee applicability or to avoid wrong decisions.

Fantasy: Results of fantasy stimulating methods use heuristic data and therefore reflect what is already known, even if the methods are strongly dependent on creativity. An integration of external stimuli should be considered in future work.

Shaping: Shaping methods offer a good opportunity to work towards the desired future, but usually ignore disruptive and fast changes. These environments must also be included.

Scenario: Scenario techniques yield consistent pictures of the future but the application is high in effort and based on qualitative data. Implementation of quantitative methods might lower the effort while maintaining the validity of results.

Analysing the Presence, Finding opinion: These methods differ from one another. One could only consider that a heuristic analysis of the presence can only lead to a limited understanding of the future.

\section{Conclusions and outlook}

In a volatile environment with decreasing time-to-market as well as shorter product and technology lifecycles, a corporate foresight to anticipate and adapt to emerging technologies is needed more than ever. Big companies in the field of engineering are applying a wide range of foresight methods, but several small and medium-sized enterprises still hesitate to use such methods. By analysing which existing methods are used in industry and researching criteria for the application of such methods, a decision tool for foresight methods was developed. Thus, an applicant of such methods can take an informed decision of which method best fits his needs using the presented tool. For each set of methods, potential for future work is identified. The next steps are to transform the results in Figure 3 into a decision tree for further facilitation of applicability. A broader validation with industrial practitioners is also envisioned. 


\section{References}

Amer, M., Daim, T.U. and Jetter, A. (2013), “A review of scenario planning”, Futures, Vol. 46, pp. 23-40. https://doi.org/10.1016/j.futures.2012.10.003

Ansoff, H.I. and McDonnell, E.J. (1990), Implanting strategic management, 2nd ed., Prentice Hall, New York.

Blessing, L.T.M. and Chakrabarti, A. (2009), DRM, a Design Research Methodology, Vol. 1. Auflage, Springer London, Guildford, Surrey. https://doi.org/10.1007/978-1-84882-587-1

Bradfield, R. et al. (2005), "The origins and evolution of scenario techniques in long range business planning", Futures, Vol. 37. https://doi.org/10.1016/j.futures.2005.01.003

Burmeister, K. (Ed.) (2002), Zukunftsforschung und Unternehmen: Praxis, Methoden, Perspektiven, Z_dossier.

Butter, M. and Popper, R. (2008), "How are foresight methods selected?", Foresight, Vol. 10 No. 6, pp. 62-89. https://doi.org/10.1108/14636680810918586

Courtney, H., Kirkland, J. and Viguerie, P. (1997), "Strategy Under Uncertainty”, Harvard Buisness Review

Daheim, C. and Uerz, G. (2008), "Corporate foresight in Europe. From trend based logics to open foresight", Technology Analysis \& Strategic Management, Vol. 20 No. 3. https://doi.org/10.1080/09537320802000047

European Foresight Monitoring Network (ENFM) (2009), Mapping Foresight: Revealing how Europe and other world regions navigate into the future, EUR, $24041 \mathrm{EN}$, Office for Official Publications of the European Communities, Luxembourg.

Fink, A., Schlake, O. and Siebe, A. (2000), "Wie Sie mit Szenarien die Zukunft vorausdenken. Was Szenarien für die Früherkennung leisten und wie sie kon-kre-te Ent-schei-dun-gen unterstützen", Harvard Business Manager, No. Special Issue.

Götze, U. (1993), Szenario-Technik in der strategischen Unternehmensplanung, DUV. Wirtschaftswissenschaft, 2nd ed., Dt. Univ.-Verl. [u.a.], Wiesbaden.

Gräßler, I. (2015), "Umsetzungsorientierte Synthese mechatronischer Referenzmodelle. Implementation-oriented synthesis of mechatronic reference models", In: Bertram, T. (Ed.), Konferenzband der VDI Mechatronik: Fachtagung Mechatronik 2015, Dortmund, pp. 167-172.

Gräßler, I., Hentze, J. and Scholle, P. (2016), "Enhancing systems engineering by scenario-based anticipation of future developments", 11th International Conference on System of Systems Engineering, 12-14 June 2016, Kongsberg, Norway. https://doi.org/10.1109/SYSOSE.2016.7542938

Gräßler, I., Pottebaum, J. and Scholle, P. (2018), "Influence Factors for Innovation in Digital Self-Preparedness Services and Tools", International Journal of Information Systems for Crisis Response and Management, Vol. 10 No. 1, pp. 20-37. https://doi.org/10.4018/IJISCRAM.2018010102

Gräßler, I., Scholle, P. and Thiele, H. (2019), "Strategische Planung in Plattformen und Eco-Systemen mittels Szenario-Technik”, 27-28 July 2019, Paderborn. https://doi.org/10.17619/UNIPB/1-794

Greve, E. and Krause, D. (2018), “An Assessment of Methods to Support the Design of Future Robust Modular Product Architectures", In Faculty of Mechanical Engineering and Naval Architecture, University of Zagreb, May 21-24, 2018, Croatia; The Design Society, Glasgow, UK, pp. 335-346. https://doi.org/10. 21278/idc.2018.0249

Iden, J., Methlie, L.B. and Christensen, G.E. (2017), "The nature of strategic foresight research. A systematic literature review", Technological Forecasting and Social Change. https://doi.org/10.1016/j.techfore.2016.11.002

Kahn, H. and Wiener, A.J. (1967), year 2000; a framework for speculation on the next thirty-three years.

Keenan, M. (2007), Combining Foresight: Methods for Impact, 3rd International Conference on Foresight.

Klüfers, P. et al. (2017), "Strategic Foresight - Die Zukunft antizipieren", SIRIUS - Zeitschrift für Strategische Analysen, Vol. 1 No. 1, p. 441. https://doi.org/10.1515/sirius-2017-0004

Krystek, U. and Stewens, G.M. (1992), Frühaufklärung für Unternehmen: Identifikation und Handhabung zukünftiger Chancen und Bedrohungen, Poeschel, CE, Stuttgart.

Lichtenthaler, E. (2005), "The choice of technology intelligence methods in multinationals. Towards a contingency approach", International Journal of Technology Management, Vol. 32. https://doi.org/10.1504/ IJTM.2005.007341

Machi, L.A. and McEvoy, B.T. (2012), The literature review: Six steps to success, 2nd ed., Corwin, Thousand Oaks.

Pillkahn, U. (2008), Using Trends and Scenarios as Tools for Strategy Development, Wiley-VCH, Hoboken.

Popper, R. and Teichler, T. (2011), 1st EFP Mapping Report: Practical Guide to Mapping Forward-Looking Activities (FLA) Practices, Players and Outcomes, European Forsight Platform, Brussles.

Randt, N.P. (2015), "An approach to product development with scenario planning: The case of aircraft design", Futures, Vol. 71, pp. 11-28, https://doi.org/10.1016/j.futures.2015.06.001

Reibnitz, U.V. (1992), Szenario-Technik: Instrumente für die unternehmerische und persönliche Erfolgsplanung, 2nd ed., Gabler, Wiesbaden.

Wack, P. (1985), “Scenarios: Shooting the Rapids”, Harvard Buisness Review, Vol. 63 No. 6, pp. 139-150. 